\title{
VARIATIONS OF THE REGIME OF EXISTING GLACIERS
}

\author{
Report of a Symposium held at Obergurgl, Austria, Io-18 September I962
}

A $\mathrm{T}$ the Helsinki General Assembly of the International Union of Geodesy and Geophysics, the Commission of Snow and Ice decided to hold a Symposium on variations of the regime of existing glaciers, and this took place at Obergurgl, Austria from ro to 18 September 1962. The meetings were held in the Hotel Edelweiss und Gurgl, and about I 35 participants were housed in the local hotels and at the excellent Bundessportheim of the University of Innsbruck. The officers of the Commission and of the International Association of Scientific Hydrology had arranged matters so well that the printed Proceedings of the Symposium were dispatched some weeks before the conference opened, and the local arrangements by Professor and Frau H. Hoinkes and collaborators were of an equally high standard. As a result the Symposium was a great success, and there was adequate time for many interesting discussions on the 38 papers presented.

The majority of the papers were printed in the Proceedings, and these are all included in "Glaciological literature" at the back of this issue of the Fournal of Glaciology, so in this report I shall simply discuss some of the main trends which emerged from the meetings. Following the division of the subject suggested by the President of the Commission, Professor Shumskiy, in his opening address, we can divide the main problem of glacier variations into studies of the net budget and how it is determined by meteorological variables and other circumstances and, on the other hand, studies of the glacier flow problem, which determines how the variations of net budget express themselves the changes of dimensions of glaciers.

The net budget problem was mentioned in many of the papers. One of the first to mention it, and one of the most interesting discussions of it particularly in view of the location of the Symposium and its excursions, was that of Hoinkes and Rudolph, who listed the important quantities determining the net budget for the Ötztal glaciers as winter precipitation, summer radiation, the amount of summer snowfall, together with two quantities, the length of the ablation season and the state at the end of the preceding ablation season, which in principle ought to be determinable from meteorological variables, but which in fact are best regarded as separate factors in the situation. The importance of summer snowfall, particularly in low latitudes, was mentioned in several other papers, and Tronov discussed in detail its importance in the Altay region. Several papers discussed the factors which influenced accumulation and ablation; for example Chizhov and Koryakin found that, for the Novaya Zemlya glaciers, the mean winter temperature was correlated with accumulation and the mean summer temperature with ablation, and they used this to reconstruct the net budgets from the temperature data. Another factor influencing the amount of accumulation was thought by Fitch and others to be the general atmospheric circulation. In a critical case such as the one they had studied in Jan Mayen, the changes in accumulation could be very marked.

Besides these meteorological factors, there are other non-meteorological ones which can influence net budget, for example Kick gave instances of glaciers in central Asia which were fed by avalanches, and also other cases where the tongues were covered by thick layers of debris, and both these are factors not determined by the metcorological variables usually considered. We saw an example of this kind of influence during our excursions to the local glaciers in the Ötztal, for the 1962 summer was not one which would have given very heavy melting had it not been for a layer of dust deposited on the surfaces of the glaciers in the early ablation season by winds blowing from the south, from North Africa and Italy. Because of the decreased albedo resulting from this layer, the old snow line in the area was extremely high. Another kind of non-meteorological factor was the melting at the bottom, discussed for the Antarctic Ice Sheet by Zolitov, who had made a calculation of this taking into account the 
influence the melting has on the temperature distribution. The bottom melting or freezing under the Ward Hunt Ice Shelf was discussed in their paper by Lyons and Ragle.

The actual measurement of the net budget for the ice sheets by analysing deep cores was reported by Langway for Greenland; his results showed that the net budget had been a minimum in Greenland at the time of maximum extent of European glaciers in about i 780 . This result, which comes from agreement between oxygen isotope and other methods of identifying annual layers, is in marked contrast with the failure to get such an agreement in the Antarctic cores, where the paper of Sharp and Epstein showed that the budget determined from oxygen isotopes was somewhat greater than that determined in other ways. This introduces an uncertainty into the mass budget of the Antarctic Ice Sheet, paralleled by an uncertainty in the magnitudes of the loss terms due to the flow of the ice sheets. In their paper on this subject, Dolgushin and others conclude that the mass balance is still uncertain even as to sign, but is approximately in a state of equilibrium, a conclusion supported by the evidence round the margins of Antarctica mentioned below.

A final group of papers dealing with the net budget problem are those which sought methods of determining the net budget from aerial photographs or by other measurements made more simply than detailed studies of accumulation and ablation. The ratio of the accumulation area to the ablation area (or to the total area of the whole glacier) was used as a measure of this by Pal'gov, Hoinkes and Rudolph, and Meier and Post. This correlation promises to be very important in extending information about net budget into areas where detailed field work on the scale needed to give a proper coverage seems impossible. In this connection the use of the energy of glacierization or variation of net budget with altitude is also of importance, as emphasized in the papers of Meier and Post and of Haefeli. A warning about the application of this to very small glaciers came, however, from the paper of Eugster, who had studied two glaciers so small that they normally did not have an equilibrium line, being either completely within the ablation area or completely within the accumulation area according to the season. Other cases in which it is probably not true that a balanced budget corresponds to a definite accumulation area ratio are glaciers which end in fjords, especially if their tongues are afloat, and glaciers with their lower parts covered in debris, cases discussed by Bengtson and by Kick respectively. Müller, in the discussion, quoted an extreme case of the effect of debris; the lower part of the tongue of the Khumbu Glacier is so covered by debris that it has an altitude higher than the ice up-valley and the direction of flow has reversed.

The glacier flow problem, the connection between net budget and the change in glacier dimensions was discussed theoretically in the papers of Nye, Shumskiy and Weertman and more generally by several others. Nye's paper expanded the material presented at the January symposium of the Glaciological Society briefly reported in the October 1962 issue of the Fournal of Glaciology, by discussing the phase lag or time delay between a change in net budget and the corresponding advance of the snout as a function of the periodicity of the changes. The validity of the assumptions made in Nye's kinematic theory, in particular the assumption that the flow depends only on the position, the thickness and the surface slope, was also discussed by several speakers including Kick, who gave the example of the Chungpar Glacier, the speed of which had doubled with little change in either surface slope or thickness. In order to explain the anomalously rapid advances in some glaciers, Weertman put forward the suggestion that under certain, rather rare circumstances, a glacier might acquire a layer of melt water on its bed which could assist it to slide on its bed by lifting it clear of the smaller obstacles. In the discussion on this paper Elliston gave evidence from the Gornergletscher to support Weertman's suggestion that short term changes in glacier flow might be connected with changes in the amount of water on the bed, and it became apparent that we need to know much more about the way water flows in a temperate glacier before we can say what the mechanism of glacier sliding is. Obviously the presence of water can affect this, the extreme 
case being a glacier which comes into a region where it can float. Bengtson showed an example of just how important this could be, since the Brady Glacier in Alaska has had very little retreat over the last $200 \mathrm{yr}$. whereas most of the neighbouring glaciers have had enormous retreats. The reason for this would seem to be that the Brady Glacier ends in a fjord, and advanced very markedly like all the other similar glaciers in the eighteenth century. However at that stage it built a moraine at the end which was sufficiently big to ground the tongue, and this so changed the situation as regards loss from the end of the glacier that the change in budget which was sufficient to make all the other glaciers in the area retreat, left the Brady where it was with its snout protected from wave erosion and calving. The question of catastrophic glacier advances also came up in several other papers. Fitch and others had observed the advances of the Jan Mayen glaciers, and further had found that the surface velocities had dropped enormously - to about a twentieth-between r 959 and r 96 I. This erratic behaviour seems to be characteristic of several glaciers in the same general area for Liestøl reported that on Finsterwalderbreen in Spitsbergen the lower part of the glacier was scarcely moving while the upper part was flowing fast, and it is known that part of the ice cap Sørfonna on Nordaustlandet has had sudden advances of the type that seems to be in progress here.

Shumskiy's calculation was an attempt to solve the glacier flow problem in the light of our limited knowledge of the factors involved. He applied it to the small ice cap on Drygalski Island, and concluded that the situation there was one of very slow decrease in ice thickness. This result might seem to conflict with the conclusions of Péwé and Church that in the McMurdo Sound area the glaciers of Antarctica are remarkably stationary but the conflict is probably not real since the rates of retreat that Shumskiy is discussing are extremely small, and might well be missed in the comparative studies of photographs which form the basis of the McMurdo Sound work.

In addition to the papers which can be neatly categorized as belonging either to the net budget or the glacier flow problems, there were many that reported more generally on the variations of glaciers. For example, Finsterwalder discussed the value of the photogrammetric method in keeping a watch on glacier variations, and he outlined the kinds of glaciers which should be chosen for such studies and the observations that were needed, drawing his examples principally from the areas visited on the Symposium excursions. He pointed out the importance of measuring the changes in surface height, and not only the horizontal variations of glaciers. This point was given greater significance by Davies and Krinsley, who, in the course of a paper describing variations of glaciers over the whole of north Greenland, gave examples of ice caps which showed no retreat but were very probably getting thinner all the time, and by Müller who, in a contribution to the discussion of Lliboutry's paper, mentioned that in the Canadian Arctic there were examples of outlet glaciers which were getting thinner in their middle reaches while their tongues were advancing. Meier and Post also discussed the information that one could get from aerial photographs even if they were not repeated, giving methods for recognizing whether glaciers were advancing or retreating strongly from their snout appearance. In their paper Lliboutry, Vallon and Vivet reported detailed studies of the flow and changes in dimensions of three small areas of glacier, two areas on the large ice mass that becomes the Mer de Glace in its lower parts and also the whole of the smaller Glacier de Saint-Sorlin, a detailed study that provided the basis for a very active discussion. Lliboutry also discussed the way in which the response of glaciers can vary according to the type of topography.

A further example of the value of the photogrammetric method was provided by the paper of Regensburger, presented by Pillewizer, giving results of the resurvey of Lednik Fedchenko in Uzbekistan, the first studies of which were made by Finsterwalder in 1928. Also in central Asia, we had details of glacier variations in India from Ahmed, Jangpangi and Vohra, Kurien and Munshi, and Tewari and Jangpangi (although unfortunately none of these Indian glaciologists were able to get to Obergurgl) as well as in the paper already mentioned by 
Kick, and from the Zailiyskiy Alatau by Makarevich. From the Caucasus there was a summary paper covering an enormous amount of work over a large area from Kovalyev, and from the Arctic regions there were papers on variations in Zemlya Frantsa Iosifa by Grosval'd and Krenke, from Spitsbergen by Kosiba, from Greenland by Weidick, from Axel Heiberg Island by Müller and from Alaska by Goldthwait, McKellar and Cronk, as well as the other papers already mentioned. From the more temperate regions of the Southern Hemisphere, there was one paper, that of Heine dealing with changes in the small glaciers on Mount Ruapehu in New Zealand. There was also a general discussion of the trend of glacier retreat based on the figures from the Italian glaciers by Vanni, and a paper on rock glaciers and their connection with true glaciers by Thompson.

As well as the papers of Finsterwalder and of Hoinkes and Rudolph, there were further papers of particular interest in the context of the glaciers visited on the excursions and of the local importance of glaciers from Schatz, who reported on the measurements started by Blümcke and Hess and still being continued as an important series of continuous measurements on the Hintereisferner and Vernagtferner, and from Lanser, who discussed the role of glaciers in the economy and technical development of a country like Austria where they form such an important part of the hydrology. On the first excursion itself, to the Rotmoosferner, Kinzl gave a useful introduction to the glacial history of the area, and further excursions took members of the Symposium to the Gaisbergferner and to the Gurglerferner, all reached by easy walks from Obergurgl. During the conference there were also excursions further afield to the Zugspitze, to the Morteratsch Gletscher, and to the Ortler mountains. After the end of the Symposium there were two alternative excursions, one to the Hohe Tauern and the Pasterzenkees, led by H. Paschinger, the other to Hintereisferner, Kesselwandferner and Vernagtferner led by $\mathrm{H}$. Hoinkes. These were all most enjoyable, and for the most part the weather was good. We did see the end of the 1962 accumulation season in the Otztal Alps however, for snow fell on the evening of 17 September, and this obscured surface features of the glaciers for the final excursions. On the other hand it did enable us to see the measurements being made of the net accumulation in a pit high on Kesselwandferner, so there were compensations. As well as all these strictly glaciological sessions and excursions there was a business meeting of the Commission and several more social occasions including a banquet at the invitation of the Landeshauptmann von Tirol and a farewell party, and, after the closing of the Symposium proper, Professor Bauer showed some very interesting slides of the curious glaciers he has recently been studying in Kerguelen. An exhibition of books and pictures of the Ötztal glaciers had been assembled at the Bundessportheim that showed the remarkable amount of early work done in this area.

The part of the Symposium most hard to report on is the detailed discussion that followed practically every paper. This was often very stimulating and interesting, and it is good to know that a detailed account of the discussions is to be published in the Bulletin of the International Association of Scientific Hydrology. The whole Symposium was thus a worthy successor to that held in Chamonix four years previously, and it is to be hoped that similar success will attend the further symposia which are planned-the next being tentatively suggested as being on the subject of avalanches, at Davos in the spring of 1964 . 